\title{
Near-Harvest Applications of Metschnikowia fructicola, Ethanol, and Sodium Bicarbonate to Control Postharvest Diseases of Grape in Central California
}

\author{
Ozgur Akgun Karabulut, Uludag University, Faculty of Agriculture, Department of Plant Protection, 16384 \\ Gorukle-Bursa, Turkey; Joseph L. Smilanick, Franka Mlikota Gabler, and Monir Mansour, United States De- \\ partment of Agriculture-Agricultural Research Service, San Joaquin Valley Agricultural Sciences Center, Parlier, \\ CA 93648; and Samir Droby, Department of Postharvest Science of Fresh Produce, Agricultural Research Organi- \\ zation, The Volcani Center, Bet Dagan 50250, Israel
}

\begin{abstract}
Karabulut, O. A., Smilanick, J. L., Mlikota Gabler, F., Mansour, M., and Droby, S. 2003. Nearharvest applications of Metschnikowia fructicola, ethanol, and sodium bicarbonate to control postharvest diseases of grape in central California. Plant Dis. 87:1384-1389.

The yeast Metschnikowia fructicola, ethanol, and sodium bicarbonate (SBC), alone or in combinations, were applied to table grapes on vines $24 \mathrm{~h}$ before harvest to control the incidence of postharvest diseases. In four experiments, all significantly reduced the total number of decayed berries caused by Botrytis cinerea, Alternaria spp., or Aspergillus niger after storage for 30 days at $1^{\circ} \mathrm{C}$ followed by 2 days at $20^{\circ} \mathrm{C}$. In three experiments, a mean gray mold incidence (caused by $B$. cinerea) of 34.2 infected berries per kilogram among untreated grape was reduced by Metschnikowia fructicola at $2 \times 10^{7} \mathrm{CFU} / \mathrm{ml}$, ethanol at $50 \%(\mathrm{vol} / \mathrm{vol})$, or SBC at $2 \%$ (wt/vol) to 12.9, 8.1, or 10.6 infected berries per kilogram, respectively. Ethanol, $\mathrm{SBC}$, and $\mathrm{SO}_{2}$ generator pads were similarly effective. M. fructicola effectiveness was not improved when combined with ethanol or SBC treatments. Ethanol and yeast treatments did not harm the appearance of the grapes. M. fructicola and SBC left noticeable residues, and SBC caused some visible phytotoxicity to the rachis and berries. Ethanol applied at $50 \%(\mathrm{vol} / \mathrm{vol})$ reduced epiphytic fungal and bacterial populations by about $50 \%$ compared with controls. M. fructicola populations persisted on berries during storage when applied alone or after ethanol treatments, whereas SBC reduced its population significantly.
\end{abstract}

Additional keywords: biological control

Botrytis cinerea Pers.:Fr., Aspergillus niger Tiegh., and Rhizopus stolonifer (Ehrenb.:Fr.) Vuill. are common postharvest pathogens of table grapes in most regions of the world (6). Currently, postharvest diseases of table grapes are controlled by the postharvest application of $\mathrm{SO}_{2}$ gas, either by weekly fumigation in storage rooms or by packing grapes in polyethylene-lined boxes with $\mathrm{SO}_{2}$ generator pads. Problems associated with $\mathrm{SO}_{2}$ use include (22) the following: (i) $\mathrm{SO}_{2}$ residues that exceed the tolerance of $10 \mathrm{mg} / \mathrm{kg}$ of most countries can occur if the gas dosage is too high; (ii) unsightly bleaching injuries can occur after numerous or high dosage fumigations; (iii) $\mathrm{SO}_{2}$ cannot be used on or-

Corresponding author: J. L. Smilanick

E-mail: jsmilanick@fresno.ars.usda.gov

A portion of this work was financed by a USAIsrael BARD (Binational Agricultural Research and Development Fund) project (IS-3271-01R).

Accepted for publication 20 June 2003.

\section{Publication no. D-2003-0908-01R}

This article is in the public domain and not copyrightable. It may be freely reprinted with customary crediting of the source. The American Phytopathological Society, 2003. ganically certified grapes; and (iv) because of sulfite hypersensitivity in some people, the dietary hazard of $\mathrm{SO}_{2}$ was recognized and it was removed from the United States Food and Drug Administration "generally regarded as safe" classification in 1986 (30). Therefore, the development of alternative strategies to control postharvest decay of table grapes that are safe, effective, economical, and compatible with commercial handling is of interest.

Most table grape growers pack their grapes in the vineyard at harvest into their final commercial packages. Field packing, rather than packinghouse packing, has become popular because it minimizes postharvest handling, which incurs substantial labor costs, causes abrasion of the berry surface that removes the bloom, and the time to accomplish handling can delay cooling. To incorporate a process after harvest, such as the application of a fungicide solution by spraying or immersing the berries in it, would require additional postharvest handling and would be perceived by growers as less practical. A replacement treatment for $\mathrm{SO}_{2}$ that is applied in the vineyard before harvest would not require changes in the current harvest and packing practices and would be more feasible to incorporate into grower operations than one applied after harvest.
Alternatives to $\mathrm{SO}_{2}$ could be developed from food additives of proven safety or biological control agents. Selected organic and inorganic salts are active antimicrobial agents and are widely used food additives (21). Among these, sodium bicarbonate is used for controlling $\mathrm{pH}$, taste, and texture. It also has broad-spectrum antifungal activity (7). Bicarbonate salts applied after harvest controlled a variety of postharvest pathogens in citrus $(4,28)$, carrot $(25)$, bell pepper (10), melon (2), sweet cherry (12), and table grapes $(22,23)$. Ethanol is a common natural food component and occasional additive that possesses potent antimicrobial activity $(16,20)$. Immersion in ethanol or exposure to its vapors controlled postharvest diseases of peach, citrus fruit, and table grapes $(11,17,18,22,24,27,29)$. Biological control of postharvest diseases of table grapes has been pursued actively in several laboratories $(5,19,26,30)$. Recently, preharvest applications of the biocontrol agent, the yeast Metschnikowia fructicola Kurtzman \& Droby, sp. Nov., isolated from the surface of table grape (cv. "Superior") by Droby and coworkers (15), was shown to be effective for controlling postharvest diseases of strawberry (13).

Our objective was to evaluate near-harvest vineyard applications of sodium bicarbonate and ethanol solutions, either alone or in combination with a biocontrol agent, M. fructicola, to control postharvest diseases of table grapes. This approach could accomplish control of table grape postharvest diseases without the need of additional harvest or postharvest handling procedures, and it could reduce or eliminate the need for $\mathrm{SO}_{2}$ fumigation.

\section{MATERIALS AND METHODS}

Preharvest treatments of table grape. Experiments evaluated the control of postharvest table grape diseases by near-harvest applications of ethanol (Pharma, Brookfield, CT) at 35 and 50\% (vol/vol), sodium bicarbonate (Fisher Chemicals, Fair Lawn, NJ) at 1 and 2\% (wt/vol), and the yeast antagonist $M$. fructicola (Proyeast, Minrav Agrogreen, The Biological Division, Jerusalem, Israel). All work was conducted at the United States Department of Agriculture-Agricultural Research Service San Joaquin Valley Agricultural Sciences Center in Parlier, Fresno 
County, CA. The efficacy of these treatments was compared with water-treated grapes (control) packed with and without $\mathrm{SO}_{2}$ generators. Four experiments were conducted with three table grape cultivars. Mid-season organically grown 'Thompson Seedless' grapes were used in experiments 1 and 2 (in different vineyards), and conventionally grown late-ripening 'Princess' and 'Crimson Seedless' grapes were used in experiments 3 and 4, respectively. A randomized complete block design with four replications was used. Each replicate consisted of a row $8 \mathrm{~m}$ in length and included five vines. A volume of 1 liter of solution was applied to the grape clusters in each replicate with a 6-liter-capacity, lowpressure sprayer with an adjustable solid cone nozzle (Model 70192; H. D. Hudson Manufacturing Co., Hastings, MN).

The yeast antagonist was applied alone or in combination with ethanol or sodium bicarbonate. Dustless, water-dispersible granules containing $M$. fructicola at $2 \times$ $10^{10} \mathrm{CFU} / \mathrm{g}$ were mixed with water and applied at a rate of $2 \mathrm{~g} /$ liter. The solution contained about $2 \times 10^{7} \mathrm{CFU} / \mathrm{ml}$. When $M$. fructicola was used in combination with ethanol, the clusters were first sprayed with ethanol and the yeast was applied 45 min later. When $M$. fructicola was used in combination with sodium bicarbonate, the yeast and sodium bicarbonate were mixed together and immediately applied. All of the treatments were applied $24 \mathrm{~h}$ before harvest. From each replication, 7 to $9 \mathrm{~kg}$ of fruit were harvested and placed in ventilated polyethylene bags, each containing 600 to $700 \mathrm{~g}$ of fruit. In all, 10 or $12 \mathrm{bags}$ of grape clusters were placed in a single fiberboard box. $\mathrm{SO}_{2}$ treatment consisted of dual-release generator pads containing $7 \mathrm{~g}$ of sodium metabisulfite (Uvas Quality, Santiago, Chile). Two generator pads were placed on top and two beneath the grapes within each box, after which boxes were enclosed within plastic bags just prior to storage. The boxes were stored at 0 to $1^{\circ} \mathrm{C}$, relative humidity $>90 \%$, for $24 \mathrm{~h}$, then wrapped with polyethylene stretch film (20 $\mu \mathrm{m})$ to minimize weight loss and stem desiccation, and stored under the same conditions for about 4 weeks. The film was applied $24 \mathrm{~h}$ after the fruit were first placed in cold storage so as not to retard initial cooling. After cold storage, the polyethylene stretch film was removed and the fruit were stored at $20^{\circ} \mathrm{C}$ for an additional $48 \mathrm{~h}$ to simulate the environmental conditions that occur during market display. In one experiment, the grapes were placed at $20^{\circ} \mathrm{C}$ immediately after harvest, no polyethylene film was used, and they were examined after 6 days to simulate direct marketing of the grapes without storage. Observations were made visually by counting the number of decayed berries that showed typical symptoms of $B$. cinerea, Alternaria spp., or Aspergillus spp. infections per kilogram of fruit. Incidence data were transformed (arcsin of the square root of the proportion of infected fruit) before an analysis of variance was applied. Means were separated using Fisher's least significant difference $(P \leq 0.05)$. Results from each experiment were analyzed and are shown independently.

Influence of ethanol treatment on natural microbe populations on berries. The effect of vineyard ethanol applications on populations of epiphytic fungi on the surface of berries was determined in three experiments. One hour after ethanol or water (control fruit) was applied as previously described, 40 single berries (including pedicels) were collected using sterile scissors from 20 clusters within each of four replicate plots. Using scissors sterilized by brief immersion in $10 \%$ ( $\mathrm{vol} / \mathrm{vol})$ laundry bleach $(5.25 \%$ sodium hypochlorite; Clorox Company, Oakland CA), two berries were clipped from opposite sides of the sampled clusters and dropped into sterile plastic bags $(16.8$ by $14.9 \mathrm{~cm})$. In the laboratory, $200 \mathrm{ml}$ of sterile distilled water was added, and the bags were shaken on a rotary shaker at $200 \mathrm{rpm}$ for $30 \mathrm{~min}$. After 10 -fold serial dilutions in water, five aliquots of $10 \mu \mathrm{l}$ from each dilution were plated in petri dishes containing potato dextrose agar (PDA; Difco Laboratories, Detroit, MI) amended with chloramphenicol (Sigma-Aldrich, St. Louis, MO) at 250 $\mu \mathrm{g} / \mathrm{liter}$ to inhibit bacterial growth, and cultures were observed after $48 \mathrm{~h}$ of incubation at $24^{\circ} \mathrm{C}$. Three replicate determina- tions were made from the extract prepared from each plot. Population of fungi was expressed as CFU per berry.

Survival of $M$. fructicola on grapes during storage. Survival of the yeast antagonist $M$. fructicola on berries within clusters that had been treated with the yeast alone or in combination with sodium bicarbonate or ethanol was determined soon after application and during storage for 4 weeks at $1^{\circ} \mathrm{C}$. Samples were collected three times; $1 \mathrm{~h}$ after application in the vineyard and after 2 and 4 weeks of storage. The experiment was done twice with 'Thompson Seedless' grapes. Extracts were cultured on PDA amended with chloramphenicol at $250 \mu \mathrm{g} / \mathrm{liter}$; the sample size, method of collection, and population determination procedures were as previously described to determine the influence of ethanol treatment on natural fungal populations. M. fructicola colonies were distinguishable from the other yeasts and fungi because this yeast has characteristic pinkcolored colonies after $48 \mathrm{~h}$ of incubation on PDA.

\section{RESULTS}

Preharvest treatments with ethanol (50\%), sodium bicarbonate (2\%), M. fructicola, or their combinations reduced the number of decayed 'Thompson Seedless' berries significantly after storage at $20^{\circ} \mathrm{C}$ for 6 days (Fig. 1). These treatments were comparable in efficacy to the $\mathrm{SO}_{2}$ treatment. In all of the experiments, decayed

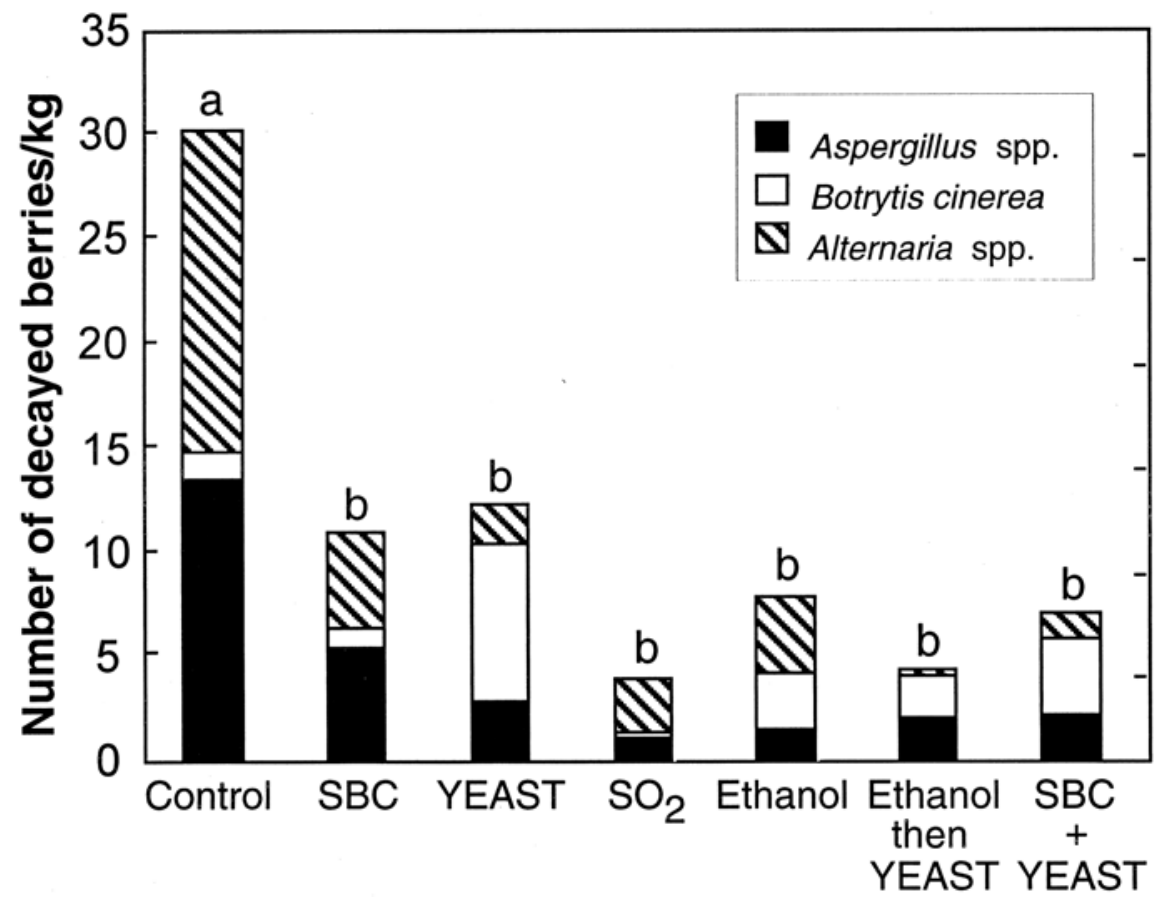

Fig. 1. Postharvest decay of 'Thompson Seedless' table grapes treated $24 \mathrm{~h}$ before harvest and stored for 6 days at $20^{\circ} \mathrm{C}$. Preharvest treatments were water (control), the yeast Metschnikowia fructicola, ethanol $(50 \% \mathrm{vol} / \mathrm{vol})$, ethanol followed by the yeast, or a combination of sodium bicarbonate $(2 \% \mathrm{wt} / \mathrm{vol}) \mathrm{and}$ the yeast. Clusters treated with water and packaged at harvest with sulfur dioxide generator sheets $\left(\mathrm{SO}_{2}\right)$ that were present throughout storage represented $\mathrm{SO}_{2}$ treatment. Clusters treated with water and packed without $\mathrm{SO}_{2}$ generator sheets represented control fruit. Within each experiment, columns with unlike letters differ significantly by Fisher's least significant difference $(P \leq 0.05)$. 
berries on which more than one pathogen was present on a single berry were rare. Dark brown Alternaria spp. and Aspergillus niger infections typically appeared on infected berries near the pedicel. Lightbrown infections of $B$. cinerea typically appeared elsewhere and the surface of the discolored flesh detached easily ("slip skin") when touched (6).

In experiment 1 , all of the near-harvest treatments applied to 'Thompson Seedless' grapes, except sodium bicarbonate at $1 \%$ (wt/vol), reduced both the total number of decayed berries and the number with symptoms caused by $B$. cinerea, Alternaria spp., or Aspergillus niger (Table 1). The effectiveness of ethanol $(50 \% \mathrm{vol} / \mathrm{vol})$ and sodium bicarbonate $(2 \% \mathrm{wt} / \mathrm{vol})$ treatments was not significantly different than that of the $\mathrm{SO}_{2}$ treatments against each of three pathogens or their total. In contrast, the effectiveness of ethanol (35\%) and sodium bicarbonate $(1 \%)$ was inferior to $\mathrm{SO}_{2}$ treatment. Neither application of ethanol before $M$. fructicola nor the combination of M. fructicola with sodium bicarbonate improved efficacy of the yeast.

The results of a second experiment with 'Thompson Seedless' grapes were similar to those of experiment 1 , with a few excep- tions (Table 1). All of the near-harvest treatments (experiment 2) significantly reduced the total number of decayed berries, as well as decay caused individually by $B$. cinerea or Alternaria spp.. Ethanol $(50 \% \mathrm{vol} / \mathrm{vol})$ applied alone or followed by M. fructicola most effectively reduced the total decay observed or that caused by each of the three pathogens alone. When either was used alone or combined, sodium bicarbonate $(2 \% \mathrm{wt} / \mathrm{vol})$ and $M$. fructicola reduced decay caused by $B$. cinerea, Alternaria spp., and Aspergillus niger about $50 \%$. Application of ethanol before $M$. fructicola or the combination of $M$. fructicola with sodium bicarbonate did not improve the efficacy of the yeast. $\mathrm{SO}_{2}$ treatment reduced the number of decayed berries by about $80 \%$ in experiment 2 compared with 50\% in experiment 1 .

In experiment 3, all treatments significantly reduced the number of decayed berries among 'Princess' grapes caused by B. cinerea and Alternaria spp. compared with the control (Table 1), and there were no significant differences among them.

In experiment 4 , ethanol ( $50 \% \mathrm{vol} / \mathrm{vol})$, sodium bicarbonate ( $2 \% \mathrm{wt} / \mathrm{vol})$, and $\mathrm{SO}_{2}$ similarly and significantly reduced the number of total decayed berries compared with the control treatment among latematuring 'Crimson Seedless' grapes (Table 1). Decay incidence was low and Alternaria spp. caused most of the infections observed.

Ethanol significantly reduced fungal populations on surfaces of berries by about $60 \%$ in all of the experiments (Fig. 2). Epiphytic bacterial populations were very low (less than 2,000 CFU/berry) and were reduced similarly by preharvest ethanol treatments (data not shown).

M. fructicola populations changed little during storage (Fig. 3). Ethanol treatment had no influence on the population size or persistence of the yeast. In contrast, the yeast population on the berries treated with a combination of the yeast and sodium bicarbonate was significantly lower than after application of the yeast alone or the yeast in combination with ethanol.

\section{DISCUSSION}

The results of this study demonstrated that near-harvest applications of ethanol, sodium bicarbonate, or the yeast antagonist M. fructicola significantly controlled postharvest diseases of table grape.

Microflora populations on berry surfaces were significantly reduced by approxi-

Table 1. Effect of preharvest treatments on postharvest decay of table grapes after storage for 30 days at $1{ }^{\circ} \mathrm{C}$ and 2 days at $20^{\circ} \mathrm{C}$

\begin{tabular}{|c|c|c|c|c|}
\hline \multirow[b]{2}{*}{ Treatment } & \multicolumn{4}{|c|}{ Number of decayed berries per kilogram ${ }^{z}$} \\
\hline & Total decay & Botrytis cinerea & Alternaria spp. & Aspergillus niger \\
\hline \multicolumn{5}{|l|}{ 'Thompson Seedless' (experiment 1) } \\
\hline Ethanol $(35 \%)$ & $19.7 \mathrm{bcd}$ & $13.1 \mathrm{bc}$ & $5.8 \mathrm{ab}$ & $0.8 \mathrm{a}$ \\
\hline Ethanol $(50 \%)$ & $15.4 \mathrm{abc}$ & $6.8 \mathrm{ab}$ & $8.5 \mathrm{ab}$ & $0.0 \mathrm{a}$ \\
\hline Sodium bicarbonate (1\%) & $25.0 \mathrm{~d}$ & $14.5 \mathrm{~cd}$ & $9.7 \mathrm{bc}$ & $0.8 \mathrm{a}$ \\
\hline Sodium bicarbonate $(2 \%)$ & $14.3 \mathrm{abc}$ & $8.8 \mathrm{abc}$ & $4.8 \mathrm{ab}$ & $0.7 \mathrm{a}$ \\
\hline Yeast & $22.5 \mathrm{bcd}$ & $13.2 \mathrm{bc}$ & $9.2 \mathrm{bc}$ & $0.0 \mathrm{a}$ \\
\hline Ethanol $(35 \%)+$ yeast & $16.2 \mathrm{bcd}$ & $8.9 \mathrm{abc}$ & $7.1 \mathrm{ab}$ & $0.1 \mathrm{a}$ \\
\hline Ethanol $(50 \%)+$ yeast & $17.6 \mathrm{bcd}$ & $10.5 \mathrm{abc}$ & $7.1 \mathrm{ab}$ & $0.0 \mathrm{a}$ \\
\hline Sodium bicarbonate $(1 \%)+$ yeast & $24.2 \mathrm{~cd}$ & $13.8 \mathrm{bc}$ & $9.8 \mathrm{bc}$ & $0.6 \mathrm{a}$ \\
\hline Sodium bicarbonate $(2 \%)+$ yeast & $14.6 \mathrm{ab}$ & $5.0 \mathrm{a}$ & $9.5 \mathrm{bc}$ & $0.1 \mathrm{a}$ \\
\hline Sulfur dioxide & $8.2 \mathrm{a}$ & $4.9 \mathrm{a}$ & $3.1 \mathrm{a}$ & $0.1 \mathrm{a}$ \\
\hline Water-treated control & $42.6 \mathrm{e}$ & $24.3 \mathrm{~d}$ & $15.0 \mathrm{c}$ & $3.3 \mathrm{~b}$ \\
\hline \multicolumn{5}{|l|}{ 'Thomson Seedless' (experiment 2) } \\
\hline Ethanol $(35 \%)$ & $30.4 \mathrm{bc}$ & $18.6 \mathrm{ab}$ & $11.7 \mathrm{ab}$ & $0.1 \mathrm{a}$ \\
\hline Ethanol $(50 \%)$ & $18.7 \mathrm{a}$ & $10.2 \mathrm{a}$ & $8.5 \mathrm{a}$ & $0.0 \mathrm{a}$ \\
\hline Sodium bicarbonate $(1 \%)$ & $37.6 \mathrm{c}$ & $21.7 \mathrm{~b}$ & $15.8 \mathrm{~b}$ & $0.1 \mathrm{a}$ \\
\hline Sodium bicarbonate $(2 \%)$ & $26.8 \mathrm{bc}$ & $13.2 \mathrm{ab}$ & $13.6 \mathrm{ab}$ & $0.0 \mathrm{a}$ \\
\hline Yeast & $28.7 \mathrm{bc}$ & $15.5 \mathrm{ab}$ & $13.0 \mathrm{ab}$ & $0.2 \mathrm{a}$ \\
\hline Ethanol $(35 \%)+$ yeast & $35.4 \mathrm{bc}$ & $19.7 \mathrm{~b}$ & $15.5 \mathrm{~b}$ & $0.2 \mathrm{a}$ \\
\hline Ethanol $(50 \%)+$ yeast & $21.0 \mathrm{ab}$ & $12.4 \mathrm{ab}$ & $8.6 \mathrm{a}$ & $0.0 \mathrm{a}$ \\
\hline Sodium bicarbonate $(1 \%)+$ yeast & $41.0 \mathrm{c}$ & $31.2 \mathrm{~b}$ & $9.8 \mathrm{ab}$ & $0.0 \mathrm{a}$ \\
\hline Sodium bicarbonate $(2 \%)+$ yeast & $27.4 \mathrm{bc}$ & $14.0 \mathrm{ab}$ & $13.3 \mathrm{ab}$ & $0.1 \mathrm{a}$ \\
\hline Sulfur dioxide & $36.7 \mathrm{c}$ & $19.6 \mathrm{~b}$ & $15.4 \mathrm{~b}$ & $1.7 \mathrm{~b}$ \\
\hline Water-treated control & $73.1 \mathrm{~d}$ & $36.5 \mathrm{c}$ & $35.4 \mathrm{c}$ & $1.2 \mathrm{~b}$ \\
\hline \multicolumn{5}{|l|}{ 'Princess' (experiment 3) } \\
\hline Ethanol $(50 \%)$ & $8.2 \mathrm{a}$ & $7.3 \mathrm{a}$ & $0.9 \mathrm{a}$ & $0.0 \mathrm{a}$ \\
\hline Sodium bicarbonate $(2 \%)$ & $11.1 \mathrm{a}$ & $9.7 \mathrm{a}$ & $1.4 \mathrm{a}$ & $0.0 \mathrm{a}$ \\
\hline Yeast & $10.8 \mathrm{a}$ & $9.9 \mathrm{a}$ & $0.8 \mathrm{a}$ & $0.0 \mathrm{a}$ \\
\hline Ethanol $(50 \%)+$ yeast & $6.1 \mathrm{a}$ & $5.5 \mathrm{a}$ & $0.5 \mathrm{a}$ & $0.0 \mathrm{a}$ \\
\hline Sodium bicarbonate $(2 \%)+$ yeast & $10.9 \mathrm{a}$ & $9.8 \mathrm{a}$ & $1.1 \mathrm{a}$ & $0.0 \mathrm{a}$ \\
\hline Sulfur dioxide & $7.0 \mathrm{a}$ & $6.0 \mathrm{a}$ & $0.9 \mathrm{a}$ & $0.0 \mathrm{a}$ \\
\hline Water-treated control & $45.1 \mathrm{~b}$ & $41.9 \mathrm{~b}$ & $3.2 \mathrm{~b}$ & $0.0 \mathrm{a}$ \\
\hline \multicolumn{5}{|l|}{ 'Crimson Seedless' (experiment 4) } \\
\hline Ethanol $(50 \%)$ & $4.2 \mathrm{a}$ & $0.8 \mathrm{a}$ & $0.9 \mathrm{a}$ & $2.5 \mathrm{a}$ \\
\hline Sodium bicarbonate $(2 \%)$ & $4.0 \mathrm{a}$ & $0.4 \mathrm{a}$ & $1.0 \mathrm{a}$ & $2.6 \mathrm{a}$ \\
\hline Sulfur dioxide & $3.1 \mathrm{a}$ & $0.5 \mathrm{a}$ & $0.5 \mathrm{a}$ & $2.1 \mathrm{a}$ \\
\hline Water-treated control & $10.4 \mathrm{~b}$ & $1.8 \mathrm{~b}$ & $2.5 \mathrm{~b}$ & $6.1 \mathrm{~b}$ \\
\hline
\end{tabular}

\footnotetext{
${ }^{\mathrm{z}}$ Means within columns within each experiment followed by unlike letters differ significantly according to Fisher's least significant difference $(P \leq 0.05)$.
} 
mately $50 \%$ compared with control treatments. Our results corroborate those of Lichter et al. (17), who reported that microbe populations were similarly reduced on grapes following their immersion in $70 \%$ ethanol. Relatively high concentrations of ethanol are required to kill fungal spores compared with vegetative bacteria (16). We found that spores of B. cinerea were more sensitive to ethanol than those of Alternaria alternata or Aspergillus niger (data not shown). The mode of action of ethanol on fungal physiology has been investigated in detail, primarily in the context of fermentation processes and under conditions of continuous and increasing stress from accumulating ethanol. The principal targets of ethanol action are membranes, but it has many other effects on fungal cells, including nonspecific denaturation of proteins and induction of water stress $(16,20)$.

In four experiments with 'Thompson Seedless', 'Crimson Seedless', and 'Princess' grapes, near-harvest applications of ethanol significantly and consistently reduced their postharvest decay. The effectiveness of ethanol at $50 \%$ was typically superior to that at $35 \%$, although the difference was not always significant (Table 1). In our study, $50 \%$ ethanol was superior or equal in efficacy to within-package sulfur dioxide generators in all experiments, but the efficacy of $35 \%$ ethanol was significantly less than that of sulfur dioxide in the first experiment. The rate at which ethanol evaporated may have influenced its efficacy in these tests. Probably, a portion of the ethanol evaporated during application, and we observed that clusters exposed to the sun usually were dry within a few minutes after treatment. We presume that vineyard applications of ethanol control these pathogens by inhibition of their spores, but this has not been determined empirically. Lichter et al. (17) reported that, when grapes were dipped into ethanol solutions, where little or no ethanol loss would occur during treatment, efficacy of 30 and $50 \%$ ethanol did not differ significantly.

Sodium bicarbonate at $2 \%$ was equal in effectiveness to within-package $\mathrm{SO}_{2}$ generators in all of the experiments, whereas sodium bicarbonate at $1 \%$ was less effective. Previous studies demonstrated that increasing concentrations of sodium bicarbonate resulted in a corresponding increase in efficacy $(9,10,13,22,23)$. The inhibitory effect of sodium bicarbonate on microorganisms may be due to a reduction of cell turgor pressure that causes a collapse and shrinkage of hyphae and spores, resulting in fungistasis (10).

Most observers believe the postharvest decay of grapes occurs primarily by infection of wounds made during harvest and packing; therefore, reducing pathogen inoculum on grapes at the time of harvest is important in managing postharvest decay

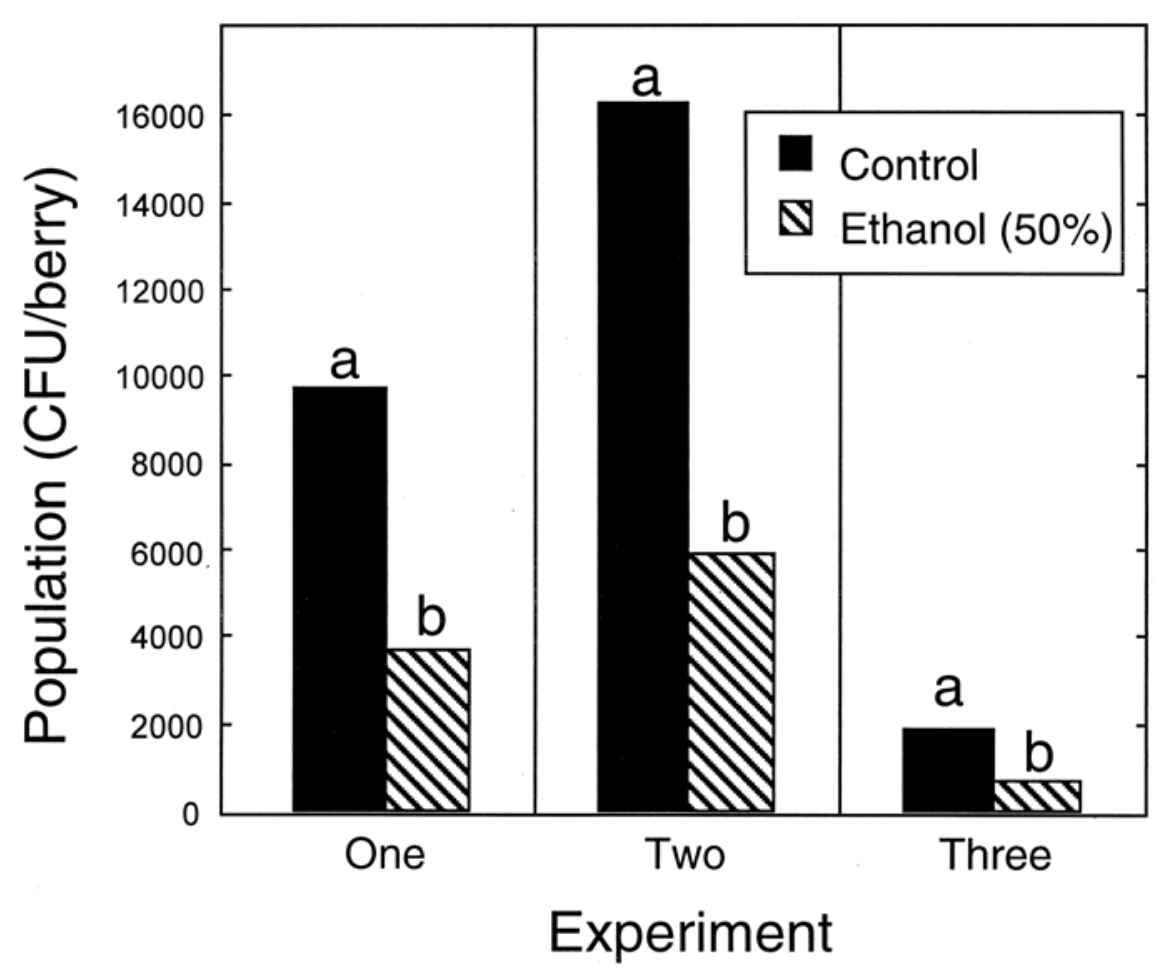

Fig. 2. Effect of ethanol (50\% vol/vol) applications to clusters on grapevines on epiphytic populations of fungi on grape berries. In experiments 1 and 2, 'Thompson Seedless' grapes were used and, in experiment 3, 'Princess' grapes were used. Within each experiment, columns with unlike letters differ significantly by Fisher's least significant difference $(P \leq 0.05)$.

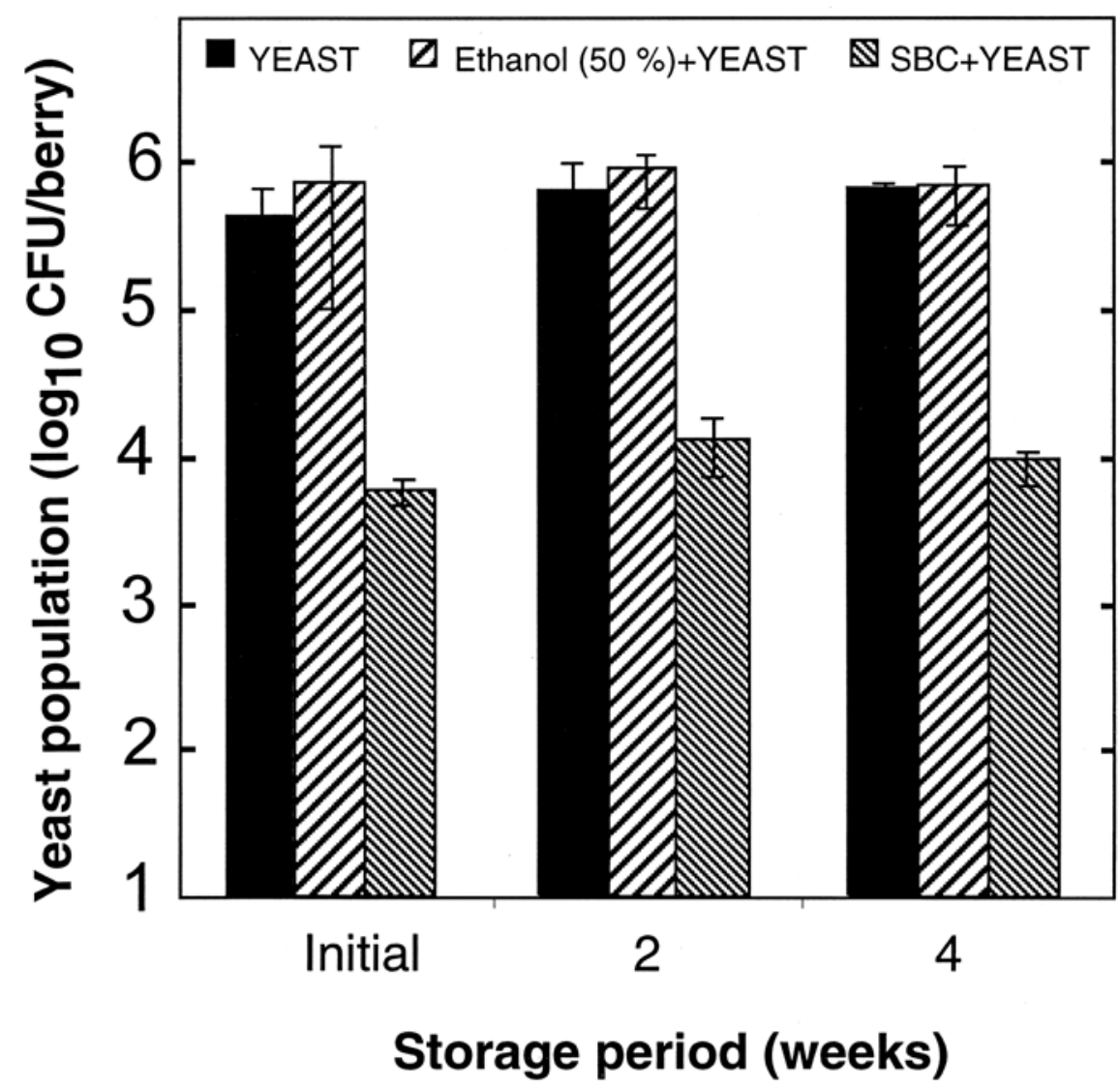

Fig. 3. Populations of the yeast Metschnikowia fructicola on 'Thompson Seedless' grape berries determined immediately after harvest ( $1 \mathrm{~h}$ after application in the vineyard) and after 2 and 4 weeks of storage at $1^{\circ} \mathrm{C}$. The yeast was applied to clusters on vines alone, co-mixed with $3 \%(\mathrm{wt} / \mathrm{vol})$ sodium bicarbonate, or $45 \mathrm{~min}$ after ethanol (50\% vol/vol) was applied. 
(8). Good sanitation before harvest and packing operations to minimize contamination of these wounds is a necessity. Treating the clusters $24 \mathrm{~h}$ before the harvest with ethanol or sodium bicarbonate reduced the number of infections, presumably by reducing inoculum and inhibiting germination of the spores of these pathogens, and this prolonged the storage and shelf life of the grapes. Careful handling also is important; the efficacy of sodium bicarbonate was significantly lower when it was applied to wounded berries (with cracks and detached pedicels) compared with its application to the berries without wounds (22).

Preharvest applications of $M$. fructicola reduced subsequent postharvest decay and were similar in efficacy to $\mathrm{SO}_{2}$ treatment in experiments 2 and 3 . Its effectiveness could be attributed to its persistence on berry surfaces under both field and postharvest conditions. Previous studies demonstrated that $M$. fructicola controlled postharvest diseases of table grape and strawberry when applied before harvest $(13,14)$. This yeast apparently is quite tolerant of arid climates, where it has been effective in many environments in other disease control applications $(1,3)$.

Combining $M$. fructicola with sodium bicarbonate or following ethanol treatment did not improve the effectiveness of the yeast. Application of ethanol before the yeast, although it did reduce the resident microbe populations on the berries, did not influence colonization of the berries by the yeast or its persistence. $M$. fructicola populations on fruit were much lower when it was co-mixed with sodium bicarbonate before application; therefore, no benefit in effectiveness by using them in combination would be expected. In another study on apple and peach, in contrast to our results, a solution of sodium bicarbonate at $2 \%$ (wt/vol) consistently enhanced performance of the yeast antagonist Candida oleophila (9).

Ethanol and yeast treatments had no impact on berry and rachis condition compared with the control treatment. We observed a slight rachis injury on clusters treated with sodium bicarbonate. These observations were in agreement with the findings of a previous study (22). Prior work showed that ethanol did not harm the appearance of table grapes, whereas sodium bicarbonate could leave a visible, topical residue and cause minor changes in rachis appearance $(17,22,23)$. In our work, the yeast treatment also left a topical residue. Most growers prefer minimal visible residues on berries at harvest. Vineyard applications of sodium bicarbonate or yeasts made with longer intervals between treatment and harvest could minimize visible residues, although the influence of longer intervals on postharvest disease control efficacy is not known.
Ethanol and sodium bicarbonate are well-studied natural substances present in many food products. Issues associated with their use should be fewer than those associated with synthetic fungicides: they should pose a minimal ingestion hazard to humans because of their low mammalian toxicity, they are inexpensive, and their effectiveness was at commercially useful levels. Application before harvest of these treatments could be readily accomplished by many growers, who already possess vineyard sprayers, but who may not have packing line facilities with tanks or drenching equipment needed to apply postharvest treatments. A practical concern with sodium bicarbonate treatments is the presence of sodium, whose addition to agricultural soils usually is avoided; therefore, substitution by the more expensive and probably less effective potassium bicarbonate $(22,23)$ may be needed in some locations. Ethanol residues in berries were not determined in our work, but they should be low because, in postharvest treatment studies, the residues on grapes and stone fruit were above natural levels but were relatively low and declined during storage $(17,18)$. The flash point of ethanol, defined as the concentration at which ignition by flame is possible, is $24^{\circ} \mathrm{C}$ for a solution containing $50 \%$ ( $\mathrm{vol} / \mathrm{vol})$ ethanol. Application of sodium bicarbonate or ethanol in vineyards to control postharvest decay has not been reviewed by regulatory agencies, and probably would need specific approval. Ethanol also is subjected to taxes and stringent regulation of its distribution in most countries.

\section{ACKNOWLEDGMENTS}

We thank S. Bader of California State University, Fresno, for assistance; and K. Mordechai from Minrav Infrastructures, The Biological Division, Jerusalem, Israel, for providing us with the yeast material.

\section{LITERATURE CITED}

1. Adams, P. B. 1990. The potential of mycoparasites for biological control of plant disease. Annu. Rev. Phytopathol. 28:59-72.

2. Aharoni, Y., Fallik, E., Copel, A., Gil, M., Grinberg, S., and Klein, J. 1997. Sodium bicarbonate reduces postharvest decay on melons. Postharvest Biol. Technol. 10:201-206.

3. Andrews, J. H. 1992. Biological control in the phyllosphere. Annu. Rev. Phytopathol. 30:603-635.

4. Armito, Y., Homma, Y., and Misato, T. 1977. The effect of sodium hydrogen carbonate on the occurrence of citrus storage diseases. J. Pestic. Sci. 2:163-167.

5. Ben Arie, R., Droby, S., Zutkhi, J., Cohen, B., Weiss, B., Sarig, P., Zeidman, M., Daus, A., and Chalutz, E. 1991. Preharvest and postharvest biological control of Rhizopus and Botrytis bunch rot of table grapes with antagonistic yeasts. Pages 100-113 in: Proc. Workshop Biol. Control Postharvest Dis. Fruits Veg. C. Wilson and E. Chalutz, eds. U. S. Dep. Agric. Res. Serv. Publ. 92.

6. Bulit, J., and Dubos, B. 1988. Botrytis bunch rot and blight. Pages 13-15 in: Compendium of Grape Diseases. R. C. Pearson and A. C. Goheen, eds. American Phytopathological Society Press, St. Paul, MN.
7. Corral, L. G., Post, L. S., and Montville, T. J. 1988. Antimicrobial activity of sodium bicarbonate. J. Food Sci. 53:981-982.

8. De Kock, P. J., and Holz, G. 1992. Application of fungicides against postharvest Botrytis cinerea bunch rot of table grapes in the Western Cape. S. Afr. J. Enol. Vitic. 15:33-40.

9. Droby, S., Wisniewski, M., El Ghaouth, A., and Wilson, C. Influence of food additives on the control of postharvest rots of apple and peach and efficacy of the yeast-based biocontrol product Aspire. Postharvest Biol. Tech. In press.

10. Fallik, E., Grinberg, S., and Ziv, O. 1997. Potassium bicarbonate reduces postharvest decay development on bell pepper fruits. J. Hortic. Sci. 72:35-41.

11. Feliciano, A., Feliciano, J., Vendruscuolo, J., Adaskaveg, J., and Ogawa, J. M. 1992. Efficacy of ethanol in postharvest benomylDCNA treatments for control of brown rot of peach. Plant Dis. 76:226-229.

12. Karabulut, O. A., Lurie, S., and Droby, S. 2001. Evaluation of the use of sodium bicarbonate, potassium sorbate and yeast antagonists for decreasing postharvest decay of sweet cherries. Postharvest Biol. Technol. 23:233-236.

13. Karabulut, O. A., Tezcan, H., Daus, A., Cohen L., Wiess, B., and Droby, S. Biological control of preharvest and postharvest rots in strawberries by Metschnikowia fructicola. Biocontrol Sci. Technol. In press.

14. Keren-zur, M., Lazare, M., Khusid, A., Bercovitz, A., Rebhun, M., Cohen, L., Weiss, B., Daus, A., Karabulut, O. A., and Tezcan, $\mathrm{H}$ 2002. Development and commercial testing of the yeast Metschnikowia fructicola for the control of pre and postharvest diseases. Page 69 in: Proc. Seventh Meet., May 22-26, 2002. IOBC-EFPP. Y. Elad, J. Kohl, and N. Delen, eds. EBILTEM, Ege University, Kusadasi, Turkey.

15. Kurtzman, C. P., and Droby, S. 2001. Metschnikowia fructicola, a new ascosporic yeast with potential for biocontrol of postharvest fruit rots. Syst. Appl. Microbiol. 24:395399.

16. Larson, E. L., and Morton, H. E. 1991. Alcohols. Pages 191-203 in: Disinfection, Sterilization, and Preservation. Fourth ed. S. S Block, ed. Lea and Febiger, London.

17. Lichter, A., Zutkhy, Y., Sonego, O. D., Kaplunov, T., Sarig, P., and Ben-Arie R. 2002. Ethanol controls postharvest decay of table grapes. Postharvest Biol. Technol. 24:301308 .

18. Margosan, D. A., Smilanick, J. L., Simmons, G. F., and Henson, D. J. 1997. Combination of hot water and ethanol to control postharvest decay of peaches and nectarines. Plant Dis. 81:1405-1409.

19. McLaughlin, R. J., Wilson, C. L., Droby, S., Ben-Arie, R., and Chalutz, E. 1992. Biological control of postharvest diseases of grape peach and apple with the yeasts Kloeckera apiculata and Candida guilliermondii. Plant Dis. 76:470-473.

20. Mishra, P. 1993. Tolerance of fungi to ethanol. Pages 189-208 in: Stress Tolerance of Fungi. D. H. Jennings, ed. Marcel Dekker, New York.

21. Miyasaki, K. T., Genco, R. J., and Wilson, M. E. 1986. Antimicrobial properties of hydrogen peroxide and sodium bicarbonate individually and in combination against selected oral gram-negative facultative bacteria. J. Dental Res. 65:45-48.

22. Mlikota Gabler, F., and Smilanick, J. L. 2001. Postharvest control of table grape gray mold on detached berries with carbonate and bicarbonate salts and disinfectants. Am. J. Enol. Vitic. 52:12-20. 
23. Mlikota, F., and Smilanick, J. L. 1998. Control of Botrytis cinerea and postharvest gray mold on grapes with carbonate and bicarbonate salts. (Abstr.) Phytopathology 88:S64.

24. Ogawa, J. M., and Lyda, D. 1960. Effects of alcohols on spores of Sclerotinia fructicola and other peach-rotting fungi in California. Phytopathology 50:790-792.

25. Punja, Z. K., and Gaye, M. M. 1993. Influence of postharvest handling practices and dip treatments on development of black root rot on fresh market carrots. Plant Dis. 77:989-995.

26. Schena, L., Ippolito, A., Zahavi, T., Cohen, L.,
Nigro, F., and Droby, S. 1999. Genetic diversity and biocontrol activity of Aurobasidium pullulans isolates against postharvest rots. Postharvest Biol. Technol. 17:189-199.

27. Smilanick, J. L., Margosan, D. A., and Henson, D. J. 1995. Evaluation of heated solutions of sulfur dioxide, ethanol, and hydrogen peroxide to control postharvest green mold of lemons. Plant Dis. 79:742-747.

28. Smilanick, J. L., Margosan, D. A., Mlikota, F., Usall, J., and Michael, I. 1999. Control of citrus green mold by carbonate and bicarbonate salts and the influence of commercial posthar- vest practices on their efficacy. Plant Dis 83:139-145.

29. Yuen, C. M. C., Paton, J. E., Hanawati, R., and Shen, L. Q. 1995. Effects of ethanol, acetaldehyde and ethyl formate vapour on growth of Penicillium italicum and $P$. digitatum on oranges. J. Hortic. Sci. 70:81-84.

30. Zahavi, T., Cohen, L., Weiss, B., Schena, L., Daus, A., Kaplunov, T., Zutkhi, J., Ben-Arie, R., and Droby, S. 2000. Biological control of Botrytis, Aspergillus and Rhizopus rots on table and wine grapes in Israel. Postharvest Biol. Technol. 20:115-124. 